\title{
Goat Milk in Human Nutrition and Health - A Review
}

\author{
Sachin S. Lad ${ }^{1}$, K.D. Aparnathi ${ }^{1}$, Bhavbhuti Mehta ${ }^{1}$ and Suresh Velpula ${ }^{2}$ \\ ${ }^{1}$ Dairy Chemistry Department, ${ }^{2}$ Dairy Engineering Department, SMC College of Dairy Science, \\ AAU, Anand, India \\ *Corresponding author
}

\begin{tabular}{|l|l|}
\hline \multicolumn{1}{l}{ A B S T R A C T } \\
\cline { 1 - 2 } $\begin{array}{l}\text { Keywords } \\
\begin{array}{l}\text { Goat milk, } \\
\text { Human nutrition } \\
\text { and health }\end{array}\end{array}$ & $\begin{array}{l}\text { Goats are earliest domesticated animals. Number of the individuals are } \\
\text { maintained them either as a source of the income or as a hobby. Mostly } \\
\text { goats are maintained as a source of the milk and were milked even before } \\
\text { cows. Goat is also called as "Cow of poor man". Many scientists focused } \\
\text { on the functional properties of the goat milk along with sheep milk. It is } \\
\text { concluded that, these milks have not only high nutritional value but also } \\
\text { therapeutic value and dietary characteristics. }\end{array}$ \\
\hline $\begin{array}{l}\text { Accepted: } \\
\text { 17 April 2017 } \\
\text { 10 Mailable Online: } 2017\end{array}$ & \\
\hline \hline
\end{tabular}

\section{Introduction}

In many countries, goat farming is the important part from the economy point of the view; especially in the Mediterranean and Middle East region. Goat farming is well organized in France, Italy, Spain and Greece (Park and Haenlein, 2006). Industrialization of the goat milk is not well successed because of its poor and insufficient volume. From 1990 , interest in the goat milk production is increased i.e. 10 million MT (1990) to 15.2 million MT (2008). Though there is increase in the production of the goat milk, still there is lack of marketing of this milk (Mahmoud, 2010). Goat milk is one of a neutraceutical health drink. As goat milk is rich in mineral and vitamin content and has creamy texture, it is used as the replacer for number of the supplements which are people consume daily. Goat milk is quite better as compared to that of cow milk because of its easy digestibility.

\section{Composition of goat milk}

Different milks have different composition. Composition of the cow, goat and human milks are mentioned in table 1. Composition of these milk are vary according to changes in diet, individuals, season, breed, species, feeding managements, environmental conditions, stage of the lactation, locality and condition of the udder.

Goat milk differs from cow and human milk in having better digestibility, buffer capacity, alkalinity and therapeutic values.

Fat of goat milk have higher physical properties i.e. surface tension, viscosity and specific gravity as compared to cow milk (Park et al., 2007). 


\section{Milk lipid}

Fat is up to $99 \%$ glycerides and steroids. The fat is present in the milk as "oil-in-water" type of emulsion. Fat globules of goat's milk observed to be similar to that of cow's milk in lipids composition and properties but goat's milk lacks agglutinin (Jenness, 1980). The average diameter of globules in goat's milk is about 1.5-2 $\mu \mathrm{m}$ compared to 2.5-3.5 $\mu \mathrm{m}$ for cow's milk and the percentage of globules of less than $1.5 \mu \mathrm{m}$ is $28 \%$ for goat's milk verses 10\% for cow's milk (Le Jaouen, 1981 and Kalantzopoulos, 1993).

Average size of the fat globules are much smaller in goat milk i.e. about $65 \%$ of the fat globules are $<3 \mu \mathrm{m}$ as compared to that of the cow milk (Park et al., 2007). That's why goat milk is considered as "self homogenized" milk. In respect to free lipids, goat milk has higher values than that of cow milk Cerbulis et al., 1982).

Goat milk has three fatty acids higher (two fold) as compared to that of cow milk i.e. $\mathrm{C}_{8}$, $\mathrm{C}_{10}$, and $\mathrm{C}_{12}$ (Juarez and Ramos, 1984).

Medium chain triglycerides (MCTs) are able to provide energy without being deposited in the fatty tissue of the body as well as it play a role in decreasing cholesterol levels in body. MCTs used for "milky urine" (chyluria) and chylothorax (lung conditions).

MVTs are also used for treating the food absorption disorders i.e. diarrhea, steatorrhea (fat indigestion), cealic disease, liver disease and digestion problems due to partial surgical removal of stomach (gasterctomy) or intestine (short bowel syndrome).

Fatty acids composition of goat milk reported by various authors and compared with those of cow milk is summarized in table 2.

\section{Milk proteins}

Two distinct phases of milk proteins are an unstable micellar phase composed of casein and a soluble composed of whey proteins. Goat milk contains lesser amounts of the $\alpha$ scasein, higher amounts of the $\beta$-casein fractions and almost equal amounts of the kcasein fractions compared to cow milk. The major protein in cow milk is $\alpha$ s1casein, while in goat milk is $\beta$ casein. Goat milk also contains equal amount ofas1-casein, but the amount and genetic variants differ between goat populations (Diaz-Castro et al., 2010). The casein micelles in goat milk differ from those in cow milk in having greater $\beta$-casein solubilisation, more calcium and phosphorus and lower heat stability (Horackoval et al., 2014).

Goat milk contains a significantly lower level of as-1 casein, a major allergen in bovine milk (Lara-Villoslada et al., 2004) (Table 3).

\section{Milk carbohydrate}

Lactose is the major carbohydrate in goat milk and the content is slightly lower than in cow milk. It is synthesized from glucose and galactose in the mammary gland, where the milk protein $\alpha$-lactalbumin plays an important role (Kunz et al., 2000). Lactose is a valuable nutrient, because it favors intestinal absorption of calcium, magnesium and phosphorous and the utilization of vitamin $\mathrm{D}$. It also is of major importance during milk synthesis and during secretion of milk into the duct system of the udder.

Other carbohydrates found in goat milk are oligosaccharides, glycopeptides, glycoproteins and nucleotides in small amounts. Goat milk is significantly rich in lactose-derived oligosaccharides compared to cow milk. Milk oligosaccharides are thought to be beneficial to human nutrition because of 
their prebiotic and anti-infective properties (LaraVilloslada et al., 2006). In animal models, goat milk oligosaccharides have been shown to have anti-inflammatory effects in induced colitis (Daddaoua et al., 2006). These results could be useful in the management of inflammatory bowel disease (Robinson, 2001).

Goat milk contains a lower concentration of oligosaccharides in comparison to human milk, it is greater than in bovine and ovine (Sheep) milks and the oligosaccharide structures identified in goat milk are most similar to that of human milk. This is particularly significant for infant nutrition as human milk oligosaccharides are greatly beneficial for the infant due to their prebiotic and anti-infective properties.

\section{Milk vitamins}

Goat milk has a higher vitamin A content than cow milk because goats convert all $\beta$-carotene from foods into vitamin $A$ in the milk (Conesa et al., 2008). For the same reason, goat milk is always whiter than cow milk. Both goat and cow milk have low concentrations of vitamin B6 and vitamin D, which are both important during infancy (Juarez et al., 2011) (Table 5).

Goat milk contains a similar amount of vitamin A as human milk. Vitamin A is important for both innate and adaptive immune responses, including cell-mediated immunity and antibody responses. Vitamin $\mathrm{C}$ is a well-known water-soluble antioxidant that is found in greater amounts in goat milk than in cow milk. This vitamin has been shown to affect many aspects of the immune system including the regulation of immunity via antiviral and anti-oxidant properties (Geissler and Powers, 2011). Goat milk is also a good source of vitamins such as D, E, thiamine, riboflavin and niacin. Goat's milk has low levels of foliate (Park, 2006).

\section{Milk mineral}

It is noteworthy that milk of each species has a particular individual pattern of minerals, which may be a pointer of the relative nutritional importance of the element.Goat milk is reported to have higher content of Potassium, Calcium, chloride, Phosphorus, Selenium, Zinc and Copper than cow milk (Krstanovic et al., 2010; Lopez-Aliaga et al., 2005).Cow milk is distinguished by a lower concentration of sodium, phosphorus, zinc, copper and manganese with respect to other milk types (goat and human milk). From the viewpoint of human nutrition, therefore the milk of goat is to be preferred to that from cow (Bunaji) due to higher content of most of the minerals. Hence goat milk, like cow milk cannot replace human milk in young children but could complement it. A greater diffusion of knowledge on nutritional value of goat milk could promote its complementary effect in human diet, mostly if used highest mineral contents compared to that of cow or human milk (Belewu and Aiyegbusi, 2002) (Table 6).

\section{Dietary and medical significance of goat milk}

Goat milk is considered as an ideal food for all the ages as it contains essential vitamin and minerals. It is one of the key healthy drink (www.draxe.com).

\section{Functional food}

Milk calcium and proteins along with the newly formed structures created by reaction of these are of great concern from the technological point of view. Milk and colostrum are rich in bioactive components which are important to regulate weight and hypertension. It also influences digestion and health properties. As goat milk is rich in such components, we can call it as a 'functional and neutraceutical' drink. 


\section{Easily digestible fats and proteins}

The size of the fat globules of the goat milk is smaller than cow milk, therefore it makes it easy to digest. The composition of the protein of the goat milk allows forming a softer curd which assists to digestive health and comfort. Caprine casein micelles contains more inorganic phosphorous and calcium, are less heat stable, are less solvated and lose $\beta$-casein more quickly than bovine casein micelle. Goat milk contains less $\alpha \mathrm{s}$ casein and often has more as2 than as1-casein (MoraGutierrez et al., 1991). $\beta$-casein and K-casein are more in the goat milk than cow milk, therefore weak gel is obtain which is beneficial for the better digestibility but it is responsible for reduced cheese yield.

\section{Lower in lactose}

Goat milk contains slightly lower lactose content than cow milk. Lactose intolerance is cause because of the deficiency of Lactase which digests milk sugar, Lactose. In patients suffering from lactose intolerance, unhydrolyzed lactose passes to large intestine. In large intestine, this unhydrolyzed lactose is fermented by microbes leading to gas formation and release of the free fatty acids which causes gastrointestinal disturbances such as diarrhea, abdominal pain and flatulence (Russell et al., 2011). Anecdotal evidences show that goat milk is easy to digest because of softer curd formation. Casein profile of goat milk allows lactose to pass through large intestine more fastly and prevents the symptoms of lactose intolerance (Robinson, 2011). However, goat milk is not recommended for the patients suffering from lactose tolerance (www.globalhealingcenter.com/naturalhealth/goat-milk-benefits). Along with its digestibility it explains that why lactose intolerance patients can enjoy goat milk without any repercussions.
Haeilein et al., (2004) indicated that treatment with goat milk typically cure 30-40 \% problem cases of childhood cow milk allergy, which can be higher in some cases (One study shows improvements in 49 out of 55 children treated with goat milk).

\section{Less allergic proteins}

An allergy is defined as an altered or abnormal tissue reaction following exposure to foreign antigen (McCullough, 2003). It is well known that proteins are essentials for the body functioning like growth, development and repair of the body. They are the most common antigens. Infants are most commonly sensitive to proteins, about 2-6\% incidence (Lara-Villoslada et al., 2004). Some researches show that, cow milk intolerance is often due to alpha s-1 casein (www.mtcapra.com/benefits-of-goat-milk-vscow-milk/). It is interesting that, the level of the alpha s- 1 casein goat milk is $89 \%$ lower than that of cow milk. Hence, it is less allergic, goat milk shown improvements in colic, minor digestive disorders, asthma and eczema over cow milk and people with cow milk sensitivities (McCullough, 2003).

Allergenicity of goat milk and cow milk in mice was studied and it is demonstrates that the goat milk is beneficial immunologically on reducing specific markers involved in the allergic response (Lara-Villoslada et al., 2004). Compared to goat milk, cow milk significantly increased markers of inflammation including cytokine interleukin-4 (IL-4) and antigen-specific immunoglobulin G1 (IgG1), key markers in hypersensitivity reactions. IgG1 binds to mast cells and promotes degranulation (the initiation of an allergic response), causing an increase in histamine levels and the resulting allergic symptoms. This reaction to cow milk was in contrast to goat milk, which did not induce an allergic response. Figure 1(A and $\mathrm{B})$ 
demonstrates the differences in $\operatorname{IgG1}(\mathrm{A})$ and histamine (B) production in response to cow milk versus goat milk administration.

Goat milk proves its anti-allergy benefits upon drinking when a similar trial in children with cow milk protein allergies was taken. Drinking of cow milk had significantly higher levels of the inflammatory marker tumour necrosis factor- $\alpha$ (TNF- $\alpha$ ) than those who consumed goat milk. TNF- $\alpha$ is a primary mediator of adverse reactions to cow milk protein including gastrointestinal distress, respiratory and cutaneous symptoms such as eczema. In addition to the lack of inflammatory effects with goat milk consumption, subjects who drank goat milk also had higher levels of the antiinflammatory cytokine IL-10. IL-10 which suppresses the formation of pro-inflammatory cytokines such as TNF- $\alpha$ and is thought to contribute to immune suppression and thus prevent reactions to antigens in cow milk (Albenzio et al., 2012), table 7 shows the effect of cow milk compared to goat milk on these allergenic markers.

\section{Anti-inflammatory and anti-mucousal properties}

Cow milk may responsible for the allergens because of its protein fractions, while goat milk is not. On other hand, along with these, cow milk contains high content of fat than goat milk which may increase mucous buildup. Goat milk not causes irritation in the gut, because the size of the fat globules of the goat milk is one ninth the size of cow milk fat globules.

Goat milk plays a key role in almost all biological reactions and exerts antioxidant and anti-inflammatory effects in the body. This is important as inflammation is the body's primary response to infection and oxidation has been linked to the development of many diseases, including cancer. Furthermore, other factors such as the maintenance of a healthy intestinal micro flora with the help of probiotics and prebiotics (Also contained in goat milk) are essential for protecting against the negative effects of pathogenic infection allergy (Shea et al., 2004).

\section{Heart health}

Low-density lipoprotein (LDL) is such atherogenic lipoprotein which transports cholesterol from the liver to the blood vessels and is often called "The bad cholesterol". The "good" cholesterol is the high-density lipoprotein (HDL) which transports cholesterol from the vessels to the oxidative modification of LDL (ox-LDL) plays a pivotal role in atherosclerosis progression. This implies that antioxidants, which could inhibit LDL oxidation, should be effective in suppressing atherosclerosis (Lindqvist, 2008).

Proteins of the goat milk are important source of the angiotensin converting enzyme (ACE), antihypertensive peptide and inhibitory peptides. They are able to control microbial infection and also provide disease defense. Minor milk proteins include immunoglobulins, lactoferrin, transferrin, proteose peptone, ferritin, calmodulin (calcium binding protein), prolactin and folate binding protein. Non-protein nitrogen (NPN) of human and goat milk is higher than that of the cow milk. Taurine in the goat milk which is derived from the sulphur-containing amino acid has important metabolic functions as does carnitine - important nutrient for neonate. As is evident from table 2, the mineral and vitamin content of goat milk are mostly higher than that of cow milk (Park et al., 2007) (Table 4).

Goat milk is better than cow milk in monounsaturated fatty acids (MUFA), 
polyunsaturated fatty acids (PUFA) and medium chain triglycerides (MCT). These are beneficial for the cardiovascular conditions. Along with these, goat milk has lower level of the cholesterol than cow milk (Haenlein, 2004). Because of the balanced fatty acid profile of the goat milk, it helps to prevent atherosclerosis, heart attacks, strokes and other heart complications. High potassium content of the goat milk reduces the blood pressure.

Goat milk exerts hypocholesterolemic effect. Goat milk consumption reduces plasma triglyceride and hence had positive effect on lipid metabolism (Lopez-Aliaga et al., 2005). Goat milk is reported to reduce the total cholesterol level and maintain adequate triglycerides and transaminases (glutamate oxaloacetate transaminase (GOT) and glutamate pyruvate transaminase (GPT) indicators for liver intoxication). This makes goat milk to control and prevent coronary heart diseases (CHDs). (www.globalhealingcenter.com/naturalhealth/goat-milk-benefits).

\section{Immunity booster}

Selenium is one of the key component for the immune system functionality. Small amount of the selenium are found in the cow milk, but significant amount of the same found in goat milk. Hence, goat milk and its products are acts as immunity booster and able to protect an individual from illness.

Many types of cells are involved in the innate and adaptive immune response, with $\mathrm{T}$ lymphocytes (T-cells), Natural Killer (NK) cells and B-lymphocytes (B-cells) as the main players. Although immunoglobulin's (Ig) are similar in structure, minor differences within the main immunological classes (IgG, IgM, $\operatorname{IgA}, \operatorname{IgD}$ and $\operatorname{IgE}$ ) are associated with a variety of biological properties and $\operatorname{IgG}$ and $\operatorname{IgA}$ account for the majority of serum immunoglobulins. A number of factors influence our immune health and nutrition in particular is main determinant of the body's immune response.

Even if goat milk might not be a perfect alternative for people with cow milk allergy, very recent studies have showed immunomodulatory effects from goat milk both in in-vitro and human studies. Recently investigated the effects of goat milk on human blood cells in terms of nitric oxide (NO) and cytokine release, the results demonstrated that goat milk was able to activate NO release from blood cells as well as triggering of cytokine production (IL-10, TNF-a and IL-6). The NO release could have cardio-protective effects in the milk consumer and also expose antibacterial activity and thereby prevent infections.

\section{Better nutrient uptake efficiency}

As the chemical composition of the goat milk is much closer to that of the human milk, it easily assimilates in the body. Therefore it enhances the bioavailability of the nutrients present into it. Authors reported that, goat milk consumption increases the uptake of Iron and Copper in digestive tract (Gajewska et al., 1997).

\section{Prebiotic supplement}

Goat milk has higher level of the oligosaccharides as human milk than cow milk. It is well known that, these acts as prebiotics in gut and improve the health of the digestive tract (Raynal-Ljutovac et al., 2008). They are responsible for the beneficial bacteria i.e. Bifidobacteria in the intestine. Bifidobacteria exert a wide range of health benefits including immune-stimulation, prevention of pathogenic infections, anticarcinogenic activity and cholesterol lowering activity in addition to improving lactose maldigestion (Russell et al., 2011). 


\section{Ultra-nourishing}

In naturopathic medicine, goats are referred as bioorganic sodium animals whereas, cow are calcium animals. Bioorganic sodium is an important key element in maintaining joints mobile and limber. Goat milk provides $35 \%$ of our daily needs of calcium in a cup. Along with these, just a cup of goat milk provides up to $20 \%$ of daily needs of riboflavin. Along with phosphorous, goat milk contains high level of the potassium and Vitamin B12.

Goat milk improves $\mathrm{Zn}$ bioavailability, a mineral with antioxidant capacity (Zago and Oteiza, 2001). The better nutritive utilization of goat milk fat (Alferez et al., 2001) provides a lower substrate for lipid peroxidation and consequently decreases the generation of free radicals in this type of milk, explaining once more the lower TBARS levels found in the groups animals consuming the goat milk. The positive role on genomic stability of the habitual consumption of goat milk, even during Fe-overloading feeding regime, fact that could be due, at least in part to the high bioavailability of $\mathrm{Mg}$ and $\mathrm{Zn}$ (Diaz-Castro et al., 2009), together with its better fat quality (Alferez et al., 2001). Magnesium metabolism enhances genomic stability because of the following: DNA is continuously damaged by environmental mutagens and by endogenous processes. To keep mutation frequencies low, cells have evolved different types of DNA repair systems. Nucleotide excision repair is mainly involved in the removal of DNA damage induced by environmental mutagens and $\mathrm{Mg}$ is an essential cofactor in virtually all steps of nucleotide excision repair. Secondly, endogenous DNA damage is mainly repaired by base excision repair (BER) (Hartwig, 2001).

\section{Anti-carcinogenic}

Goat milk has a high content of conjugated linoleicacid (CLA) (Jirillo et al., 2010). Anticarcinogenic properties of CLA have been reported against mammary and colon cancer (Liewet al., 1995) in animal models, as well as in vitro models of human melanoma (Shultz et al., 1992) colorectal and breast cancer (Durgam and Fernandes, 2000). The mechanism by which CLA inhibit tumor development is not fully understood, although perturbation of the eicosanoid-dependent cell signaling systems, anti-oxidative effects and disturbance of the receptor mediated actions of estrogen have all been suggested by fermented goat milk (Jirillo et al., 2010).

Table.1 Chemical composition and caloric value of ruminants and human milk

\begin{tabular}{|l|l|l|l|}
\hline Components & Cow & Goat & Human \\
\hline Total solids & 12.3 & 13.2 & 12.4 \\
\hline Fat & 3.4 & 4.0 & 3.8 \\
\hline Total protein & 3.2 & 3.6 & 1.2 \\
\hline Casein & 2.5 & 2.9 & 0.4 \\
\hline Whey protein & 0.65 & 0.61 & 0.70 \\
\hline Lactose & 4.6 & 4.5 & 7.0 \\
\hline Minerals & 0.7 & 0.8 & 0.2 \\
\hline Energy $(\mathrm{kcal} / 100 \mathrm{~g})$ & 66 & 70 & 63 \\
\hline
\end{tabular}

Source: (Alichanidis and Polychroniadou 1996) 
Table.2 Fatty acids composition percent of goat's milk reported by different authors and compared with those of cow's milk

\begin{tabular}{|c|c|c|c|c|c|c|}
\hline Acid & Goat milk & & & & & Cow milk \\
\hline & $\begin{array}{l}\text { Garcia } \\
\text { al., } 1979\end{array}$ & $\begin{array}{l}\text { Boccignone } \\
\text { et al., } 1981\end{array}$ & $\begin{array}{ll}\text { Sawaya } & e t \\
a l ., 1994 & \end{array}$ & $\begin{array}{l}\text { Martin } \\
\text { Hernandez } \\
\text { et al., } 1986\end{array}$ & $\begin{array}{l}\text { Hellin et al., } \\
1998\end{array}$ & $\begin{array}{l}\text { Martinez- } \\
\text { Castro et } \\
\text { al., } 1979\end{array}$ \\
\hline C 4.0 & 2.3 & 1.81 & 3.0 & $1.8-2.8$ & 3 & $2.5-6.2$ \\
\hline C6.0 & 2.7 & 2.03 & 2.0 & $2.2-3.4$ & 6.3 & $1.5-3.8$ \\
\hline C8.0 & 3.2 & 2.68 & 2.0 & $2.4-3.9$ & 2.9 & $1.0-1.9$ \\
\hline C10.0 & 11.5 & 8.45 & 6.1 & $8.8-13.4$ & 10.4 & $2.1-4.0$ \\
\hline C12.0 & 5.3 & 5.21 & 2.9 & $3.8-5.5$ & 5.6 & $2.3-4.7$ \\
\hline C14.0 & 10.4 & 10.52 & 9.5 & $8.5-11.6$ & 12.38 & $8.5-12.8$ \\
\hline C14.1 & - & 0.96 & 0.4 & $0.5-0.8$ & - & $0.6-1.5$ \\
\hline C16.0 & 24.9 & 24.33 & 28.6 & 23.3-32.1 & 34.8 & $24.0-33.3$ \\
\hline C16.1 & - & 2.58 & 2.5 & $1-2$ & - & $1.3-2.8$ \\
\hline C18.0 & 9.7 & 9.49 & 10.3 & $4.3-11.2$ & 6.8 & $6.2-13.6$ \\
\hline C18.1 & 21.6 & 23.96 & 26.3 & $16.2-26.6$ & 13.3 & $19.7-31.2$ \\
\hline C18.2 & 1.6 & 1.68 & 2.6 & $1.2-2.5$ & 3.9 & $1.36-5.2$ \\
\hline C18.3 & 1.2 & - & - & 0 & 0.9 & - \\
\hline
\end{tabular}

Table.3 Comparison of protein content in goat milk and cow milk

\begin{tabular}{|c|c|c|c|c|c|}
\hline Protein & Goat milk & Cow milk & R.S.D. $^{\mathrm{a}}$ & $\begin{array}{l}\text { Level of } \\
\text { significance }\end{array}$ & $\begin{array}{l}\text { Difference } \\
(\%) \text { for goat } \\
\text { milk }^{\mathrm{b}}\end{array}$ \\
\hline Casein $(\mathrm{Cn})$ & 82.70 & 82.65 & 0.76 & $\mathrm{NS}^{\mathrm{c}}$ & \multirow{5}{*}{-62.8} \\
\hline$\alpha$ s1-Cn & 18.92 & 30.80 & 1.71 & -- & \\
\hline$\alpha$ s2-Cn & 8.52 & 7.50 & 1.83 & NS & \\
\hline$\beta+\mathrm{k}-\mathrm{Cn}$ & 55.26 & 44.35 & 2.79 & -- & \\
\hline $\begin{array}{l}\text { Whey } \\
\text { proteins }\end{array}$ & 17.30 & 17.35 & 0.76 & NS & \\
\hline
\end{tabular}

${ }^{\mathrm{a}} \mathrm{R} . \mathrm{S} . \mathrm{D}=$ residual standard deviation.Source: (Ceballos et al. 2009)

${ }^{\mathrm{b}}$ Difference $(\%)$ for goat milk $=[($ goat milk value - cow milk value $) /$ goat milk value $] * 100$

${ }^{\mathrm{c}} \mathrm{NS}=\mathrm{P}>0.05 ;--\mathrm{P}<0.001$

Table.4 Comparison of amino acids content in goat milk and cow milk

\begin{tabular}{|l|l|l|}
\hline Particulars & Goat & Cow \\
\hline Arginine & 277 & 277 \\
\hline Histidine & 387 & 387 \\
\hline Isoleucine & 370 & 355 \\
\hline Leucine & 330 & 339 \\
\hline Lysine & 426 & 384 \\
\hline Methionine & 381 & 395 \\
\hline Phenylalanine & 337 & 346 \\
\hline Threonine & 354 & 324 \\
\hline Tryptophan & 259 & 270 \\
\hline Valine & 381 & 349 \\
\hline
\end{tabular}

Source: (Haenlein, 2001) 
Table.5 Vitamin content of ruminant and human milk

\begin{tabular}{|l|l|l|l|}
\hline Vitamins (per 100 g) & \multicolumn{3}{|c|}{ Milk } \\
\hline & Goat & Cow & Human \\
\hline Vitamin A (IU) & 185 & 126 & 190 \\
\hline Vitamin D $(\mathrm{IU})$ & 2.3 & 2.0 & 1.4 \\
\hline Thiamine $(\mathrm{mg})$ & 0.068 & 0.045 & 0.017 \\
\hline Riboflavin $(\mathrm{mg})$ & 0.21 & 0.16 & 0.02 \\
\hline Niacin $(\mathrm{mg})$ & 0.27 & 0.08 & 0.17 \\
\hline Pentathenic acid $(\mathrm{mg})$ & 0.31 & 0.32 & 0.20 \\
\hline Vitamin b6 $(\mathrm{mg})$ & 0.046 & 0.042 & 0.011 \\
\hline Folic acid $(\mu \mathrm{g})$ & 1.0 & 5.0 & 5.5 \\
\hline Biotin $(\mu \mathrm{g})$ & 1.5 & 2.0 & 0.4 \\
\hline Vitamin B12 $(\mu \mathrm{g})$ & 0.065 & 0.357 & 0.03 \\
\hline Vitamin C $(\mu \mathrm{g})$ & 1.29 & 0.94 & 5.00 \\
\hline
\end{tabular}

Source: (Park et al., 2007)

Table.6 Mineral content of ruminant and human milk

\begin{tabular}{|l|l|l|l|}
\hline Constituents & \multicolumn{3}{|c|}{ Type of Milk } \\
\hline & Goat & Cow & Human \\
\hline & Minerals (mg/100 g) & \\
\hline $\mathrm{Ca}$ & 134 & 122 & 33 \\
\hline $\mathrm{P}$ & 121 & 119 & 43 \\
\hline $\mathrm{Mg}$ & 16 & 12 & 4 \\
\hline $\mathrm{K}$ & 181 & 152 & 55 \\
\hline $\mathrm{Na}$ & 41 & 58 & 15 \\
\hline $\mathrm{Cl}$ & 150 & 100 & 60 \\
\hline $\mathrm{S}$ & 28 & 32 & 14 \\
\hline $\mathrm{Fe}$ & 0.07 & 0.08 & 0.20 \\
\hline $\mathrm{Cu}$ & 0.05 & 0.06 & 0.06 \\
\hline $\mathrm{Mn}$ & 0.032 & 0.02 & 0.07 \\
\hline $\mathrm{Zn}$ & 0.56 & 0.53 & 0.38 \\
\hline $\mathrm{Souce}$ & &
\end{tabular}

Source: (Park et al., 2007)

Table.7 Cytokine levels ( $\mathrm{pg} / \mathrm{ml})$ in lymphocytes of children stimulated against protein fractions of cow and goat milk

\begin{tabular}{|c|c|c|c|c|c|c|}
\hline \multicolumn{7}{|c|}{$\begin{array}{l}\text { Cytokine levels (pg/ml) in cultured supernatants of lymphocytes of children against protein } \\
\text { fractions of cow and goat milk }\end{array}$} \\
\hline & \multirow[t]{2}{*}{ Species } & \multicolumn{3}{|c|}{ Milk protein fraction } & \multirow[t]{2}{*}{ SEM } & \multirow{2}{*}{$\begin{array}{l}\text { Effects, } P \\
\text { Species }\end{array}$} \\
\hline & & $\begin{array}{l}\text { Protein } \\
\text { mixture }\end{array}$ & Casein & $\beta-\lg$ & & \\
\hline \multirow[t]{2}{*}{ TNF- $\alpha$} & Cow & $833.67 \mathrm{~A}$ & $1362.38 \mathrm{bA}$ & $2401.81 \mathrm{bB}$ & \multirow[t]{2}{*}{220} & \multirow[t]{2}{*}{$*$} \\
\hline & Goat & 651.02 & $380.37 \mathrm{a}$ & $366.45 a$ & & \\
\hline \multirow[t]{2}{*}{ IL-10 } & Cow & $236.82 \mathrm{aA}$ & 482.17B & $242.49 \mathrm{~A}$ & \multirow[t]{2}{*}{70} & \multirow[t]{2}{*}{$*$} \\
\hline & Goat & $460.94 \mathrm{bB}$ & $448.81 \mathrm{AB}$ & $441.94 \mathrm{AB}$ & & \\
\hline \multirow[t]{2}{*}{ IL-12 } & Cow & 164.66 & 106.64 & 210.21 & \multirow[t]{2}{*}{52} & \multirow[t]{2}{*}{ NS } \\
\hline & Goat & 130.61 & 74.05 & 173.3 & & \\
\hline
\end{tabular}

Mean followed by different letters differ for $P<0.05$ : a and $\mathrm{b}$ for species effect; $\mathrm{A}$ and $\mathrm{B}$ for milk fraction effect. NS, not satisfactory

${ }^{a}$ protein mixture-casein; whey protein $(80: 20 \mathrm{w} / \mathrm{w}), ; * P<0.05$.Source: (Albenzio et al. 2012) 
Fig.1A and B Serum levels of $\mathrm{IgG1}$ and Histamine following Cow Milk (CM) and Goat Milk (GM)
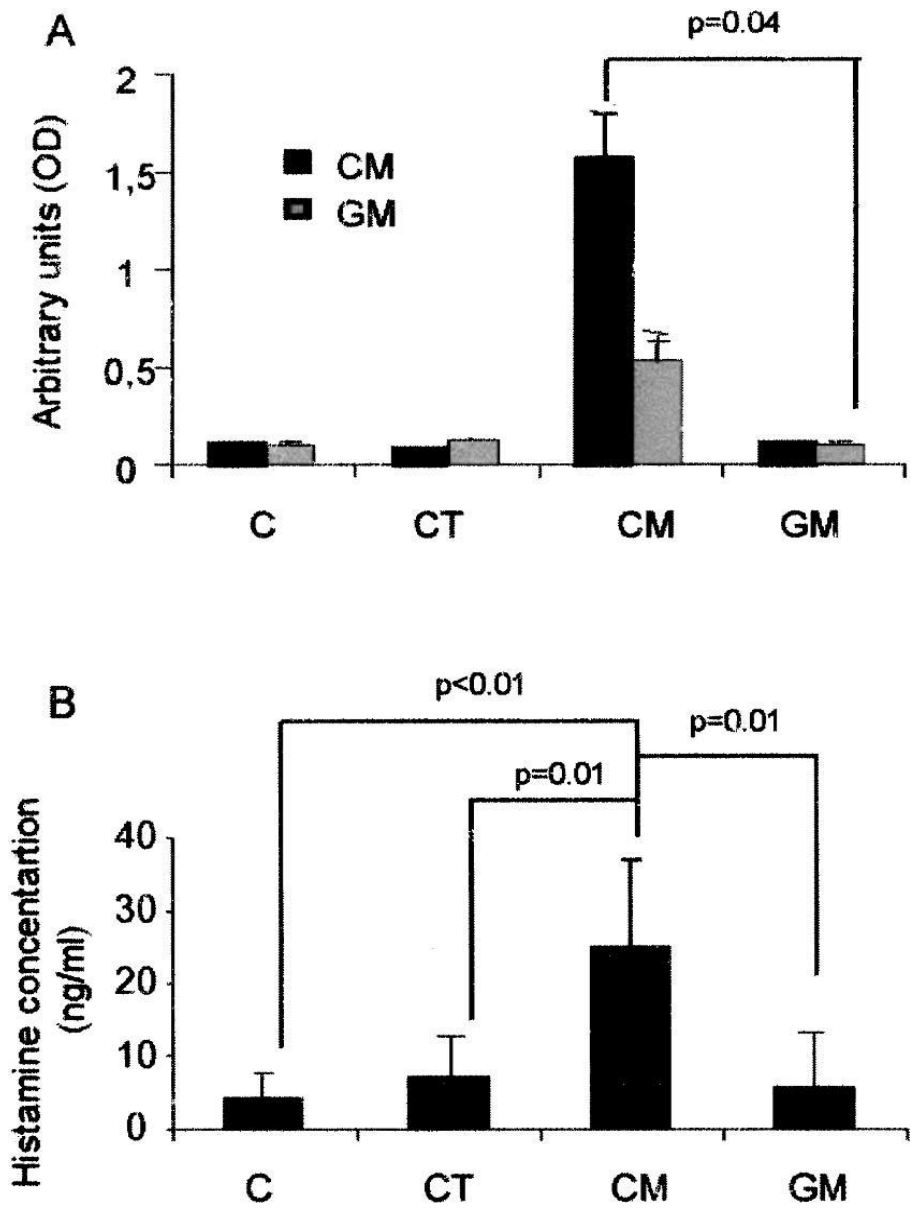

\section{Conversion of milk into products}

Goat milk is produced at small farms traditionally. Goat milk and its products were manufactured and consumed since long period of the time. Fresh milk obtained under sanitary conditions from properly fed and managed healthy goats is free from objectionable odour and flavor (Roy and Vadodaria, 2006). Well known products from the goat milk are Roquefort cheese and Leben. On other hand, goat milk is not suitable for the preparation of Ghee. The reason behind it is relatively small sized fat globules which cause problems during the fat separation and its associated odour and flavor. Goat milk is a good source for the preparation of the Infant formulae.
Recently, utilization of the goat milk for product manufacturing increases because of its known functional properties and health benefits, along with Cheese and Yoghurt, different products are manufactured from goat milk such as UHT, evaporated milk, pasteurized beverages, ice-cream, milk powder and traditional goat milk products (Pandya and Ghodke, 2007).

On other side, goat milk cause "goaty" and "mutton" flavor. Along with these, if goat milk products are to be used in replacement diets, it is necessary to incorporate folic acid supplements, as goat milk is poor in the folic acid (Pandya and Khan, 2006). 
In conclusion, researchers suggest that, "goat milk can be considered to be a neutraceutical health drink". Goat milk is the good source for those who are suffer from the cow milk protein allergy or intolerance to cow milk. Along with these, who are suffering from anemia, osteoporosis and malabsorption, they should go for goat milk. Now days, because of the functional and neutraceutical properties of goat milk, goat milk gained major attention and increased its demand. Goat milk is better for the infants and growing children, bur caution should be exercised that this milk should be supplemented with nutrient like folic acid, which is deficient in it.

\section{References}

Albenzio, M., Campanozzi, A., D'Apolito, M., Santillo, A., Petioello Mantovani, M. 2012. Differences in protein fraction from goat and cow milk and their role on cytokine production in children with cow's milk protein allergy. Small Ruminant Res., 105: 202-205.

Alferez, M.J.M., M. Barrionuevo, I. LopezAliaga, M.R. Sanz-Sampelayo and F. Lisbona, 2001. Digestive utilization of goat and cow milk fat in malabsorption syndrome. J. Dairy Res., 68: 451-461.

Belewu, M.A. and Aiyegbusi, O.F. 2002. Comparison of the Mineral Content and Apparent Biological Value of Milk from Human,Cow and Goat. J. Food Technol., Africa, 7: 9-11.

Ceballos, L., Morales, E., de la Torre Adarve, G., Diaz Castro, J., Martinez, L., Remedios, S. 2009. Composition of goat and cow milk produced under similar conditions and analyzed by identical methodology. J. Food Composition and Analysis, 22: 322-329.

Conesa, C., L. Sanchez, C. Rota, M. Perez, M. Calvo and S. Farnoud, 2008. Isolation of lactoferrin from milk of different species; calorimetric and antimicrobial studies. Comp Biochem. Physiol., 150: 131-139.

Daddaoua, A., V. Puerta, P. Requena, A. Martinez Ferez, E. Guadix, F. Sanchezde Medina, A. Zarzuelo, M.D. Suarez, J. Boza and O.
MartinezAugustin, 2006. Goat milk oligosaccharidesare anti-inflammatory in rats with hapten induced colitis. $J$. Nutrition, 136: 672-676.

Diaz-Castro, J., M.J.M. Alferez, I. Lopez-Aliaga, T. Nestares and M.S. Campos, 2009. Effect of calcium-supplemented goat or cow milk on zinc status in rats with nutritional ferropenic anaemia. Int Dairy J., 19: 116121.

Diaz-Castro, J., S. Hijano, M.J.M. Alferez, I. Lopez-Aliaga and T. Nestares, 2010. Goat milk consumption protects DNA against damage induced by chronic iron overload in anaemic rats. Int Dairy, J., 20: 495-499.

Haelein, G.F.W. 2001. The nutritive value of Sheep Milk. Inter. J. Anim. Sci., 160: 253268.

Haelein, G.F.W. 2004. Goat milk in human nutrition. Small Rumin. Res., 51: 154-163.

Haenlein, G.F.W. 2004. Goat milk in human nutrition. Small Ruminant Res., 51: 155163.

Hartwig, A. 2001. Role of magnesium in genomic stability. Mutat Res., 465: 113-121.

Horackoval, S., P. Sedlackova1, M. Slukovaand P. Milada. 2014. Influence of Whey, Whey Component and Malt on the Growth and Acids Production of Lactobacilli in Milk. Czech J. Food Sci., 32: 526-531.

Jenness, R. 1980. Composition and characteristics of goat milk: Review. J. Dairy Sci., 63: 1605-1630.

Jirillo, F., G.D. Martemucci, A.G. Alessandro, M.A. Panaro, A. Cianciulli, M. Superbo and T. Magrone, 2010. Ability of goat milk to modulate healthy human peripheral blood lymphomonocyte and polymorpho nuclear cell function: In vitro effects and clinical implications. Curr. Pharmaceutical Design, 16: 870-876.

Juarez, M., M.C. Martin-Hernandez and M. Ramos. .2011. Biochemical characteristic of three types of goat cheese. J. Dairy Sci., 75: 1747-1752.

Krstanovic, V., V. Slacanac, R. Bozanic, J. Hardi, J. Rezessyne and M. Lucan. 2010. Nutritional and therapeutic value of fermented caprine milk. Int. J. Dairy Technol., 63: 171-189. 
Kunz, C., S. Rudloff, W. Baier, N. Klein and S. Strobel, 2000. Oligosaccharides in human milk: structural, functional and metabolic aspects. Annu Rev. Nutr., 20: 699-722.

Lara-Villoslada, F., Olivares, M., Jimenez, J., Boza, J., Xaus, J. 2004. Goat milk is less immunogenic than cow milk in a murine model of atopy. J. Pediatric Gastroenterol., 39: 354-360.

Liew, C., H.A. Schut, S.F. Chin, M.W. Pariza and R.H. Dashwood. 1995. Protection of conjugated linoleic acids against 2-mino-3methylimidazo-4, 5-quinoline-induced colon carcinogenesis in the F344 rat inhibitory mechanisms. Carcinogenesis, 16: 3037-3043.

Lindqvist, H. 2008. Influence of herring (Clupeaharengus) intake on risk, Department of chemical and biological engineering. Goteborg: Chalmers University of Technology.

Lopez-Aliaga, I., M.J. Alferez, M.T. Nestares, P.B. Ros, M. Barrionuevo and M.S. Campos, 2005. Goat milk feeding causes an increase in biliary secretion of cholesterol and a decrease in plasma cholesterol levels in rats. J. Dairy Sci., 88: 102-141.

McCullough, F. 2003. Nutritional evaluation of goat's milk. Health Food J., 105: 239-251.

Park, Y.W. 1994. Hypo-allergenic and therapeutic value of goat milk. Small Rumin. Res., 14: 151-161.

Park, Y.W. 2006. Goat Milk- Chemistry and Nutrition. In: Handbook of Milk of NonBovine Mammals. Y.W. Park and G.F.W.
Haenlein, eds. Blackwell Publishers. Ames, Iowa and Oxford, England. Pp. 34-58.

Park, Y.W., M. Juárez, M. Ramos, and G.F.W. Haenlein. 2007. Physico-chemical characteristics of goat and sheep milk. Small Ruminant Res., 68: 88-113.

Raynal-Ljutovac, K., Lagriffoul, G., Paccard, P., Guillet, I., Chilliard, Y. 2008. Composition of goat and sheep milk products: An update. Small Ruminant Res., 9: 57-72.

Robinson, F. 2001. Goats milk - a suitable hypoallergenic alternative. British Food J., 108: 192-208.

Roy, S.K. and Vadodaria, V.P. 2006. Goat Milk and Its Importance. Indian Dairyman, 57: 76-81.

Russell, D., Ross, R., Fitzgerald, G., Stanton, C. 2011. Metabolic activities and probiotic potential of Bifidobacteria. Int. J. Food Microbiol., 149: 88-105.

Shea, O., M. Bassaganya, J. Riera and I.C.M. Mohede. 2004. Immunomodulatory properties of conjugated linoleic acid. American Society for Clin. Nutrition, 79: 1199-1206.

Shultz, T.D., B.P. Chew, W.R. Seaman and L.O. Luedecke, 1992. Inhibitory effect of conjugated dienoic derivatives of linoleic acid and $\beta$-carotene on the in-vitro growth of human cancer cells. Cancer Lett., 63: 125-133.

Zago, M.P. and P.I. Oteiza. 2001. The antioxidant properties of zinc: interactions with iron and antioxidants. Free Radic. Biol. Med., 31: $266-274$.

\section{How to cite this article:}

Sachin S. Lad, K.D. Aparnathi, Bhavbhuti Mehta and Suresh Velpula. 2017. Goat Milk in Human Nutrition and Health - A Review. Int.J.Curr.Microbiol.App.Sci. 6(5): 1781-1792. doi: https://doi.org/10.20546/ijcmas.2017.605.194 